\title{
Water Pollution Management and detection techniques: a Review
}

\section{Saniya Ansari a,}

${ }^{a}$ Department of Electronics \& Telecommunication Engineering, DYPSOE, Pune- 411044, India

* Corresponding Author: ansari.saniva6@gmail.com

Received: 28-(04-2021, Revised: 20-05-2021, Accepted: 24-05-2021, Published: 30-05-2021

Abstract: Now a day's water pollution became a national and global issue not only in India but over the whole world. Like India other countries are also facing the same problem of water pollution due to agricultural waste, industrial waste, sewage waste and so on. In this paper it has been explained clearly with the help of considerable number of references. It gives the information about the pollutants which pollutes the water. Sensors have a ability to Control and monitor the quality of water as well as able to detect the contaminants added due to human generating activities. Sensors can be used for the selection and identification of the techniques which will be suitable for performing the given task that is identification of pollutants present in water. Various pollutants found in water are pesticides, harmful chemicals, heavy metals, nutrients, etc. We will also going to discuss about the different techniques used for water pollution detections. Tethered.

Keywords: Sensors, Water Pollutants, Pesticides, Heavy metals, Sensor Network. Water pollutants, Detection techniques.

\section{Introduction}

Water is more important in our life like a core, it keeps us alive. It is essential to all of us to drink clean and pure water. Because of anthropogenic and natural sources, water becomes polluted. Pollutants added in to water are need to remove whether it is added by intentionally or unintentionally to protect human health from various types of diseases. Like India other states are also affected by pollution of water due to impurities added by industrial and agricultural discharge. The amount of largest discharged of sewages into the lakes and rivers, affects not only on environment but also on human beings too. Students and common people need to gives the educational information and should awareness programs to understand the importance of nature as well as environment to reduce the problem as certain level [1].

Monitoring of water environment is one of the great task for prevent human health. Pollution of water occurs when harmful chemicals and substances or pesticides contaminate added into river, lake, sea, well, ocean or other water bodies. According to fundamental rights of 
human, pure and clean is the top most priority of life. However, urbanization and increasing industrial growth all have degraded the natural water resources [2].

\section{A) Types of Water Pollutions:}

\section{Chemical Pollution}

Because of human activity when chemicals resulting into the environment, that time it is called as Chemical pollution. Examples of chemical pollution are water, soil, acid rain, greenhouse gases, ozone gas contaminating air [3].

\section{Groundwater}

At the time of rain falls it seeps deep into the earth, filling maximum the crevices, cracks and empty space of earth called as groundwater. Which is most important natural resources. It is collected by pumping process. Generally it is clean water so it can be use for drinking purpose. Groundwater gets polluted because of contaminants added by pesticides and fertilizers later seeps into lakes, rivers, and sea [4].

\section{Surface water}

As we know 70 percent area of earth has been covered by water. Surface water get fills into rivers, lake, sea, ocean etc. as per survey maximum area of rivers, streams and lake has been polluted which can not be used for swimming, fishing or dinking purpose. Agricultural area has major sources of pollutants which later added into rivers [4].

\section{Ocean water}

Ocean pollution may occurs because of oil spills or leaks of harmful chemicals or liquid at the time of transportation form one location to another. The contaminants such as chemicals, nutrients, petrol, oil and heavy metals are carried from farms, factories dropped into the river and bay at last it travel out to sea.

\section{Point Source}

Point source pollution is define as the origination of contamination from single source called as point source. For examples, the waste water discharged through manufacturing companies, oil refinery dumping into the rivers by legal or illegal process. It is generated from a specific place and its affect miles and miles waterways of rivers, sea and ocean [5].

\section{Nonpoint source}

Contamination derived from diffuse sources called as nonpoint source pollution. It includes storm water runoff, agricultural waste from land. The main drawback of this pollution is, it is difficult to regulate. 


\section{Trans boundary}

The contamination water spilling from one country water into another country water called as trans boundary pollution. Contamination like an oil spiller the slow, downriver creep of municipal, agricultural, industrial discharge.

\section{Agriculture pollution}

In India as well as over the world agricultural play a major role in water pollution. Large quantity of drugs, pesticides, saline and agrochemicals are drain into the river or other water bodies [6].

\section{Sewage and wastewater}

Waste water is nothing but the used water. Our day to day life examples of waste water are our sinks, showers, industrial and agricultural activities. There is other term called as storm water runoff, it may occurs when rainfall carries roadside impurities, oil, grease, chemicals, pesticides which laterally added into rivers and lakes or sea [6].

\section{Related Work:}

As we know some pollutants are occurs naturally like heavy metals, nitrogen oxide etc. Some pollutants can be formed during their chemical reaction with naturally occurring components like in agriculture or pharmaceuticals industries while use of concentration and transformation of chemical substrate in agricultural or industrial use. Sewage waste water generation comprising heavy metals, pesticides, agriculture waste and petrochemical hydrocarbon are examples of pollutants. The syntheses of pesticides, plastics, petrochemicals are the main source of pollutants created in the environment [7].

We all knows that clean water is more important than anything else. We can not compromise in it. Water pollution is disturbs aquatic environment because of introduction of harmful contaminants into water bodies. Now a days water pollution became a global issue, it requires some evaluation ideas and water monitoring to control $n$ avoiding water pollution [8]. There are categories of water pollutants like bacteria, disease causing agents, viruses, parasitic worms all are enter into sewage systems. Second category of pollutants is waste that can be decomposing by oxygen requiring bacteria.

Initially there was less number of research to monitor for water environment perception it was based on sensor networks and identification and selection of perfect solution on water pollution monitoring. Water environment is not easy to monitor its complex and challenging task. For examples, waves, reflection of water, color difference of water increase the level of difficulty for visual perception. In static pollutant water are stationary while in dynamic pollutants water are floating means it is difficult to control them by using traditional or normal approach. Sensor nodes may use for controlling and monitoring purpose but it required large computational power and maximum energy so it will be competent to operate image processing 
operations. Vision based sensor nodes for aquatic medium, prototype for low cost help to provide a reliable solution for continuously monitoring of water environment [9].

With the help of main parameters like dissolved oxygen, temperature, $\mathrm{pH}$, electrical conductivity we are able to monitor the quality of water in lakes, ponds and rivers. Concentration of dissolved oxygen must be low, temperature and $\mathrm{pH}$ must be undesirable are lead to poor quality of water. Pollutants carried out by storm water may content bacteria, nutrients, litter, oils, heavy metals and sediments [10].

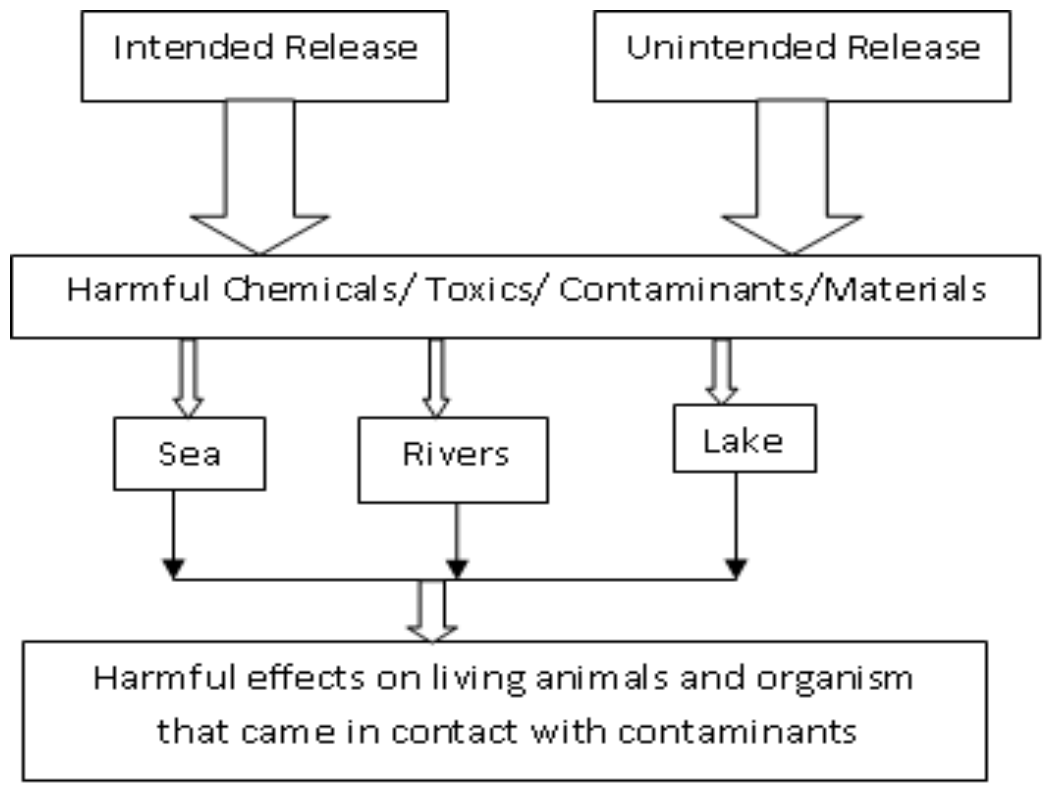

Figure 1. A diagram to represent the release of harmful pollutants into various water bodies.

Sources of Water Pollutants with effects and their solutions:

\begin{tabular}{|c|c|c|}
\hline Sources & Effects & Solutions \\
\hline $\begin{array}{l}\text { Industries effluents } \\
\text { 1. Electroplating and } \\
\text { electronic plants } \\
\text { 2. Beverage and food } \\
\text { processing } \\
\text { industries } \\
\text { 3. Rubber industry }\end{array}$ & $\begin{array}{l}\text { 1. In organism highly toxic } \\
\text { accumulate through food chain } \\
\text { 2. Human nervous disorder may } \\
\text { cause lack of presence of } \\
\text { mercury } \\
\text { 3. Waste water contains } \\
\text { contaminates like sulphaide, } \\
\text { hydrogen }\end{array}$ & $\begin{array}{l}\text { 1. Effluents should be } \\
\text { treated before } \\
\text { discharging it into water. } \\
\text { 2. Make a separate suit for } \\
\text { dumping the hazardous } \\
\text { wastes. }\end{array}$ \\
\hline
\end{tabular}




\begin{tabular}{|c|c|c|}
\hline $\begin{array}{l}\text { 1. Untreated sewage } \\
\text { contain domestic } \\
\text { waste and human }\end{array}$ & $\begin{array}{l}\text { Solid Suspended } \\
\text { 1. Penetration of light has been } \\
\text { reduced } \\
\text { 2. Decompose process require } \\
\text { high oxygen for suspended } \\
\text { solids like biodegradable, } \\
\text { microorganisms }\end{array}$ & $\begin{array}{l}\text { 1. Sewage should be treated } \\
\text { before dumping into } \\
\text { rivers } \\
\text { 2. Farm lorry should be } \\
\text { stop for entering into } \\
\text { ponds or rivers }\end{array}$ \\
\hline $\begin{array}{l}\text { 1. Domestic waste } \\
\text { contain detergents } \\
\text { and food waste }\end{array}$ & $\begin{array}{l}\text { Detergent } \\
\text { 1. Oxygen supply reduce due to } \\
\text { hard detergents foam } \\
\text { 2. Soft detergents contain high } \\
\text { phosphate as its biodegradable, } \\
\text { it rise eutrophication. }\end{array}$ & $\begin{array}{l}\text { 1. Use of low phosphates } \\
\text { biodegradable detergents }\end{array}$ \\
\hline
\end{tabular}

\section{Various Methods for Pollutants Detection in Water:}

There are various methods of water pollutants detection. In this paper we are going to discuss few techniques like electrochemical technique, chromatography, colorimetric detection of water and sensors techniques. Water pollutants contain heavy components like metals, pesticides, harmful chemicals, agricultural waste.

\section{Electrochemical}

In this technique electrochemical biosensors are attached with valuable apparatuses to identified small sample volume [14,15]. Electrochemical biosensors are basically use for continuously progress in manufacture of biomedical, ecological and agricultural process [16]. Electrochemical procedures is help to detect poisons which stored as a conduct metric, aerometric, voltammetry and last potentiometric. Exceptional structure acknowledgement makes a biosensors an appropriate option for techniques based on chromatography [17]. Electrochemical sensors have various advantages like real time monitoring, more sensitive and selective improvement. It response for electrical signals, so the complicated components use for signaling process are not important. The compact clinical framework testing has been monitor by using electrochemical techniques in local environment [14].

\section{Chromatography}

This method is used for the process of separation of mixture and acquire data from both qualitative and quantitative. Chromatography methods have different divisions of phases like, free phase also called as mobile phase, sample free phase it remain fixed also called as stationary phase $[17,18]$. This process divides the segment between two process one is mobile phases and 
stationary phase. When sample moves through mobile it capture mobile phase. It require shorter time to complete. While distribution ratio support to the stationary phase. It takes longer time to complete the framework. Mobile phase required shorter time to complete. By using this two phases mobile and stationary it is easy to isolate for solutes distribution ratio.

Water monitoring is important to avoid health related problem. Various methods are use for monitoring the pollution in water. To control and monitor the pollution it requires fast $\mathrm{n}$ rapid techniques to identify the quality of water. Chromatography techniques is used for the identification and detection of water pollutants like organic and inorganic pollutants present on ground water, surface water and marine water.

\section{Colorimetric}

There are various techniques available for pollutants detection in water. This methods includes inductively plasma mass coupled spectrometry, $\mathrm{X}$ ray florescence spectrometry and absorption and at last electrochemical analysis [19,20]. Colorimetric methods provide the actual result of impurities present in water like metal ions, harmful chemical impurities present in water. But this method is vey cost effective and only available in sophisticated laboratories. Because it is unable to handle outside of the lab. It can not perform its operation on field site. To operate and monitor this instrument of machineries highly experienced and skilled person is required. Main drawback of this process is that its very time consuming. Chemical contaminants present in water are color less so it can not detected by observing human eye. The main chemicals available in water are $\mathrm{pH}$, dissolved oxygen-O2 (or DO), temperature, electrical conductivity Oxidation reduction potential (ORP), turbidity and dissolved ions (Fluoride (Fluoride (F-), Calcium (Ca2+), Nitrate (NO3-), Chloride (Cl-), Iodide (I-), Cupric (Cu2+), Bromide (Br-), Silver $\left(\mathrm{Ag}^{+}\right)$, Fluoroborate (BF4-), Ammonia (NH4), Lithium ( $\left.\mathrm{Li}^{+}\right)$, Magnesium (Mg2+), Nitrite (NO2), Perchlorate (ClO4), Potassium $\left(\mathrm{K}^{+}\right)$, Sodium $\left(\mathrm{Na}^{+}\right)$. etc.

\section{Sensors used in water pollution detection}

\section{Micro fluidic Sensors}

Now a days it is trending to developed a more and new sensing devices with advanced features for performing a better operation on field. Sensor should be highly sensitive, low cost, easy to monitor and handle and perform specific task. Micro fluidic sensors are basically used for detection of non biological contaminants available in water like heavy metals, pesticides, mercury, arsenic, phosphate [14,15]. This type of sensors provide biological assay as well as chemical assay with minimum quantity of samples consumed also there chemical reaction to monitor microenvironment [17]. For the process of fabrication on microfluidic sensors materials like PDMS, silicon, glasses have been used. Recently Microfluidic sensors have been use for the process of water monitoring $[18,20]$. 


\section{Biosensors}

A smart device provide analytical information for quantitative and semi quantitative parameters with the help of receptor (biochemical receptor) called as biosensors [21]. It is an independent device. For a specific analytical task a biological device work as a receptor. In this process the signal detection transformation is done by transducer into a quantitative signals. The main advantage of biosensor is that it's a miniature device, it has ability to perform in complex situation. It is basically used for on site usage. Main drawback of this sensor is unable to compete with other standard sensors having issue of exact accuracy and duplicability. Biosensor have been classified in various types like electrochemical, optical, thermal biosensors and piezoelectric based on the transducing property [21]. Only the bio recep tor can able to define the functionality of biosensors. Biosensors can be classified into various classes like gas sensors also call as DNA biosensors, immune sensors, enzymatic biosensors and tissue based biosensors. All this type are depending on bio receptor only [22].

\section{Wireless Sensor Networks}

In traditional methods all samples are collected by manually and send it to laboratories for finding the contaminants available in polluted water. This traditional method of finding contaminants in water required special instruments and equipment's, highly knowledgeable and trained person to monitor. Main drawback of traditional methods are, it is more time consuming, very costly, and monitoring for real time is not possible. To overcome this drawback of traditional methods situ methods has been designed for real time monitoring for water pollution. With this process it is possible to monitor quality of water, store that data. But drawback is its difficult to send data automatically to the user for next process. So to overcome this failure researchers have given maximum attention towards wireless sensor networks (WSN) to monitor the quality of water. Sensor are able to collect the real time data, on site fixing is possible, adjustable sampling frequency, visualization and data processing can possible at any time. Remotely monitoring and controlling can be possible.

\section{Smart Sensors}

Smart sensors comes under intelligent devices, it can easily take or captured input from environmental factors. Smart sensors built in programmable microprocessors. Basically Smart sensors are sensing element, used for amplification of signals, filtering process for the combination of compensation and software data processing [23]. The data of real time monitoring of water quality by using the multisensory network given by cloete et [24].

All monitored data has been processed analytically and later it transmitted wirelessly to the allocated destination nodes to provide the information to the end user about water quality monitoring. It content parameters like temperature, $\mathrm{pH}$, turbidity, dissolved oxygen and conductivity [25]. 


\begin{tabular}{|l|l|l|}
\hline \multicolumn{1}{|c|}{$\begin{array}{c}\text { Detection } \\
\text { Methods }\end{array}$} & \multicolumn{1}{|c|}{ Observations } & \multicolumn{1}{|c|}{ Limitations } \\
\hline 1.Electrochemical & $\begin{array}{l}\text { 1.Recognize little sample volumes } \\
\text { 2.Real-time monitoring possible }\end{array}$ & $\begin{array}{l}\text { System has more } \\
\text { completion. }\end{array}$ \\
\hline 2.Chromatography & $\begin{array}{l}\text { 1.Use for separate and mixture } \\
\text { qualitative and quantitative data. }\end{array}$ & Time consuming \\
\hline 3.Colorimetric & 1.Gives accurate Result & $\begin{array}{l}\text { 1. system is very costly } \\
\text { 2.System available in labs } \\
\text { only } \\
\text { 3.costly }\end{array}$ \\
\hline
\end{tabular}

\begin{tabular}{|l|l|l|}
\hline Sensors & Observations & Limitations \\
\hline $\begin{array}{l}\text { 1. Micro fluidic } \\
\text { Sensors }\end{array}$ & $\begin{array}{l}\text { It is possible to provide both } \\
\text { biological and chemical assay. }\end{array}$ & 1. System is very cost effective \\
\hline 2. Biosensors & $\begin{array}{l}\text { 1. Able to perform in complex } \\
\text { situation. } \\
\text { 2. Onsite use possible } \\
\text { 3. Easy to prepare samples }\end{array}$ & \\
\hline $\begin{array}{l}\text { 3. Wireless } \\
\text { Sensor Networks }\end{array}$ & $\begin{array}{l}\text { 1. Use for real time monitoring } \\
\text { 4. Smart Sensors }\end{array}$ & 1. Costly \\
\hline
\end{tabular}

\section{Conclusion}

As per the overall survey of water quality monitoring we realized that it is more challenging to find out the actual method for pollutants detection and monitoring of water. Techniques should be satisfied conditions like early warning detection, quick response, cost effective, reliable, more important it continuously detection the contaminants in water. Real and continuous water monitoring is a hard task. The appropriate use of various methods for pollutants monitoring and different sensor to monitor and control water contaminants has been discussed in this paper. This paper focus on functionality and working of biosensors at various environmental conditions. Now a days sensors technology is more appreciable as it more accurate and suitable for water pollutants monitoring. The combination of analytical methods (techniques) and smart sensors leads with the effective implementation result in water pollutant monitoring process. 


\section{References:}

[1] Singh, J., Yadav, P., Pal, A. K., \& Mishra, V. (2020). Water pollutants: Origin and status. In Sensors in Water Pollutants Monitoring: Role of Material, Springer, Singapore. 5-20.

[2] Tóth, J. (2009). Origin, distribution, formation, and effects. Groundwater-Volume I, 27.

[3] Dwivedi, A. K. (2017). Researches in water pollution: A review. International Research Journal of Natural and Applied Sciences, Water Pollutants: Origin and Status, 4, 118142.

[4] Sophocleous, M. (2002). Interactions between groundwater and surface water: The state of the science. Hydrogeology Journal, Water Pollutants: Origin and Status, 10, 52-67.

[5] Rao, D. S. (2015). Thermal pollution-Impact on living organisms. International Journal of Engineering Research and Sports Science, Water Pollutants: Origin and Status, 2.

[6] Savci, S. (2012). An agricultural pollutant: Chemical fertilizer. International Journal of Environmental Science and Development, Water Pollutants: Origin and Status, 3, 73.

[7] Ahmed, S., \& Ismail, S. (2018). Water pollution and its sources, effects \& management: a Case Study of Delhi. International Journal of Current Advanced Research, 7(2), 10436-10442. http://dx.doi.org/10.24327/ijcar.2018.10442.1768

[8] Gowri, A., \& Kathiravan, A. (2020). Fluorescent chemosensor for detection of water pollutants. In Sensors in Water Pollutants Monitoring: Role of Material, Springer, Singapore. 147-160

[9] Wang, Y., Zhang, X., Chen, J., Cheng, Z., \& Wang, D. (2019). Camera sensor-based contamination detection for water environment monitoring. Environmental Science and Pollution Research, 26(3), 2722-2733. https://doi.org/10.1007/s11356-018-3645-Z

[10] Koparan, C., Koc, A. B., Privette, C. V., \& Sawyer, C. B. (2018). In Situ Water Quality Measurements Using an Unmanned Aerial Vehicle (UAV) System. Water, 10(3), 264. https://doi.org/10.3390/w10030264

[11] Singh,J., Yadav, P., Pal, A. K., \& Mishra, V. (2020). Water Pollutants: Origin and Status. Sensors in Water Pollutants Monitoring: Role of Material, Advanced Functional Materials and Sensors, 5-20. https://doi.org/10.1007/978-981-15-0671-0 2

[12] Briggs, D. (2003). Environmental pollution and the global burden of disease. British medical bulletin, 68(1), 1-24. https://doi.org/10.1093/bmb/ldg019

[13] Haseena, M., Malik, M. F., Javed, A., Arshad, S., Asif, N., Zulfiqar, S., Hanif, J. (2017). Water pollution and human health. Environmental Risk Assessing Remediation, 3(1), 16-19. https://doi.org/10.4066/2529-8046.100020

[14] Arduini, F., Cinti, S., Scognamiglio, V., Moscone, D., \& Palleschi, G. (2017). How cutting-edge technologies impact the design of electrochemical (bio) sensors for environmental analysis. A review. Analytica Chimica Acta, 959, 15-42. https://doi.org/10.1016/j.aca.2016.12.035 
[15] El Harrad, L., Bourais, I., Mohammadi, H., \& Amine, A. (2018). Recent advances in electrochemical biosensors based on enzyme inhibition for clinical and pharmaceutical applications. Sensors, 18(1), 164. https://doi.org/10.3390/s180101643

[16] Hughes, G., Westmacott, K., Honey church, K., Crew, A., Pemberton, R., \& Hart, J. (2016). Recent advances in the fabrication and application of screen-printed electrochemical (bio) sensors based on carbon materials for biomedical, agri-food and environmental analyses. Biosensors, 6(4), 50. https://doi.org/10.3390/bios6040050

[17] Ronkainen, N. J., Halsall, H. B., \& Heineman, W. R. (2010). Electrochemical biosensors. Chemical Society Reviews, 39, 1747-1763. https://doi.org/10.1016/s09565663(01)00115-4

[18] Beilby, A. L. (1977). In R. L. Pecsok, L. D. Shields, T. Cairns, I. G. McWilliam (Eds.), Modern methods of chemical analysis (2nd ed.). Journal of Chemical Education, 54, A463. https://doi.org/10.1021/ed054pA463.2

[19] Frankowski, M., Ziola-Frankowska, A., Kurzyca, I., Novotny, K., Vaculovic, T., Kanicky, V., \& Siepak, J. (2011). Determination of aluminium in groundwater samples by GF-AAS, ICP-AES, ICP-MS and modelling of inorganic aluminium complexes. Environmental Monitoring and Assessment, 182, 71-84.

[20] Nie, Z., Nijhuis, C. A., Gong, J., Chen, X., Kumachev, A., Martinez, A. W., \& Whitesides, G. M. (2010). Electrochemical sensing in paper-based microfluidic devices. Lab on a Chip, 10, 477-483. https://doi.org/10.1039/b917150a

[21] Soni, R., Soni, M., \& Shukla, D. P. (2020). Emerging Techniques and Materials for Water Pollutants Detection. In Sensors in Water Pollutants Monitoring: Role of Material, Springer, Singapore. 277-297.

[22] Ivars-Barceló, F., Zuliani, A., Fallah, M., Mashkour, M., Rahimnejad, M., \& Luque, R. (2018). Novel applications of microbial fuel cells in sensors and biosensors. Applied Sciences, 8(7), 1184. https://doi.org/10.3390/app8071184

[23] Charef, A., Ghauch, A., Baussand, P., \& Martin-Bouyer, M. (2000). Water quality monitoring using a smart sensing system. Measurement, 28(3), 219-224. https://doi.org/10.1016/S0263-2241(00)00015-4

[24] Cloete, N. A., Malekian, R., \& Nair, L. (2016). Design of smart sensors for real-time water quality monitoring. IEEE Access, 4, 3975-3990.

[25] Yifan, K., \& Peng, J. (2008). Development of data video base station in water environment monitoring oriented wireless sensor networks. In: 2008 International Conference on Embedded Software and Systems Symposia, IEEE. Springer Nature Singapore Pte Ltd. 281-286.

\section{Acknowledgements}

The authors declare that they have no conflict of interest. 


\section{Conflict of interest}

The authors declare that they have no conflict of interest.

\section{About The License}

(C) 2021 The Authors. This work is licensed under a Creative Commons Attribution 4.0 International License which permits unrestricted use, provided the original author and source are credited. 